\title{
ANALYSIS OF HEALTH SERVICES MAXIMUM SUPPLY IN HOSPITAL SURABAYA
}

\author{
Novia Dewi Putri Ayuningtyas ${ }^{1}$, Ainunnizam Azzakki Firdaus ${ }^{2}$ \\ ${ }^{1,2}$ Public Health Science, Faculty of Public Health, Universitas Airlangga \\ noviadewipa@gmail.com
}

\begin{abstract}
The importance of a health service in calculating the maximum supply is to ensure efficiency and effectiveness. To achieve efficiency and effectiveness, it is important to pay attention to the combination of Human Resources and other resources. This study aims to determine the maximum capacity of services that can be provided in Medical Rehabilitation Poly, General Surgical Poly and Children's Poly at Jemursari Islamic Hospital Surabaya. This research is a type of descriptive observational research. The subjects in this study were Medical Rehabilitation Poly, General Surgery Poly and Children's Poly at Jemursari Surabaya Hospital and the object in this study was the maximum supply in providing services in each poly. There are two data used, primary data and secondary data. Secondary data obtained from secondary data of each poly in RSI Jemursari Surabaya and primary data obtained from interviews through indepth interviews to nurses of each poly. The results of maximum supply with a history of the number of poly visits are at the Medical Rehabilitation Poly at 185 and visits at 150 patients each day, General Surgery Poly for 40 and visits at 45 patients each day, Children's Poly for 40 (Room A) and 80 (Room B) patients each day, and visits were 50 (Room A) and 50 (Room B) patients each day. So that there is an over supply situation in the Medical Rehabilitation Poly and of Children's Poly, as well as low supply conditions in the General Surgery.
\end{abstract}

Keywords : Hospital, Maximum Supply, Health Service

\begin{abstract}
ABSTRAK
Pentingnya sebuah instansi pelayanan kesehatan dalam melakukan perhitungan supply maksimal adalah untuk menjamin efisiensi dan efektifitas. Untuk mencapai efesiensi dan efektifitas, penting untuk memperhatikan kombinasi antar Sumber Daya Manusia dan sumber daya yang lain. Penelitian ini bertujuan untuk mengetahui kapasitas maksimal pelayanan yang dapat diberikan di Poli Rehabilitasi Medis, Poli Bedah Umum dan Poli Anak Rumah Sakit Islam Jemursari Surabaya. Penelitian ini termasuk jenis penelitian observasional deskriptif. Subjek dalam penelitian ini adalah RSI Jemursari Surabaya dan objek dalam penelitian ini adalah supply maksimal atau kemampuan maksimal dalam memberikan pelayanan di Poli Rehabilitasi Medis, Poli Bedah Umum dan Poli Anak . Terdapat dua data yang digunakan yaitu data primer dan data sekunder. Data sekunder didapatkan dari data sekunder masing-masing poli di RSI Jemursari Surabaya dan data primer didapat dari wawancara melalui indepth interview kepada perawat di masing-masing poli. Hasil penghitungan supply maksimum dengan history angka kunjungan poli adalah di Poli Rehabilitasi Medis sebesar 185 dan kunjungan sebesar 150 pasien per hari, di Poli Bedah Umum sebesar 40 dan kunjungan sebesar 45 pasien perhari, di Poli Anak sebesar 40 (Ruang A) dan 80 (Ruang B) pasien perhari, dan kunjungan sebesar 50 (Ruang A) dan 50 (Ruang B) pasien perhari. Sehingga terjadi keadaan over supply pada Poli Rehabilitas Medis dan Poli Anak, serta keadaan low supply pada Poli Bedah Umum.
\end{abstract}

Kata Kunci : Rumah Sakit, Suplai Maksimal, Pelayanan Kesehatan 


\section{INTRODUCTION}

In the study (Haryanto and Ollivia, 2009) stated that currently, health is one of the good business opportunities. This is evidenced by the increasing number of hospitals or private clinics. Even in Indonesia, there are also several international hospitals. Hospitals both private and government-owned try to capture as many patients as possible by improving their services.

Calculation of maximum supply must be carried out and showed by health care providers in providing services to patients and comparing with the number of actual visits that must be in the field. So, that from the maximum supply and the results of the visit found to be able to provide recommendation so that the hospital can provide efficient and effective services based on the resources provided. If the hospital or other health provider does not calculate the maximum supply, they do not understand the capacity of each unit in providing services. There can be a condition where there is an over supply where poly can improve its services but not according to the number of visits. Based on this, which can be obtained through a maximum supplu calculation, the hospital can arrange actions based on this. This is related to how to make maximum use of existing resources in the hospital so that the hospital runs optimally as well.

Based on the Law of the Republic of Indonesia Number 44 of 2009, the Hospital is a health service that provides health services that provide inpatient health service, outpatient health service, and emergency services. To carry out the effectiveness and efficiency of health care services, the hospital needs to know the capacity that can be used in health services. Hospitals also need to focus on health care from an economic perspective, namely the laws of economic supply and demand.

The concept of supply according to Yoeti, (2008) can be expressed with "the higher the price for a product, the more the amount of goods offered for sale in the market and the opposite if the price of the item goes down, then a few goods to sell on the market, because producers are reluctant to produce more because of the lack of buyers".

The definition of supply from several sources is as follows, according to (Nurjayanti, 2011) stating that supply is one of the forces that determine the market balance. Nurjayanti
(2011) also states that the supply curve shows the number of goods that producers are willing to sell at the price they will receive in the market by maintaining every factor that influences the number of offers to remain.

According to Ardiyati (2011) explains that supply is the number of goods offered by the seller in a particular market, in a certain period, and a certain price level. Ardiyati (2011) notes that prices have a positive effect on the number of goods offered, while the price of other goods will depend on the type of goods, whether substituted or complementary. Alexander Hamilton Institute (U.S.), (1994) also put forward the supply with: "What is meant by supply is several of products offered for sale with several possible prices".

Supply can be in 2 levels; there are the maximum and minimum. Supply can be in the maximum level is when the amount to be sold is at various prices. Supply can be in the the minimum level is when prices encourage sellers to offer items of various quantities. In the knowledge of supply, it is also known as ceteris paribus or discussing the relationship between the number of goods or services that will be sold or given at a price per item or price per service. The law of Ceteris paribus's offer suggests, manufacturers can offer higher prices than low prices. According to Daniel (2004), there are various factors that can influence changes in supply. These factors include technology, input prices, prices for the production of other commodities, total production, and patient expectations. Hospital is one of the producers that offer health services that are more specifically applicable to the law of supply. From several theories of supply and explanation of health provider above, we can conclude that maximum supply in health services is the maximum capacity of health services that can be produced by health providers.

Jemursari Islamic Hospital has been operating since May 25 2002, and is one of the business units under the Surabaya Islamic Hospital Foundation and has many resources to carry out health services. This research was conducted at the Jemursari Islamic Hospital Surabaya because this hospital was one of the hospitals in Surabaya that experienced significant growth. Such an increase in resources, for the example is beds, which since 2002 only had 82 beds and until 2017 the Jemursari Islamic Hospital Surabaya already 
had 238 beds. Besides that, Jemursari Hospital already has professional human resources of 748 health workers. Jemursari Islamic Hospital Surabaya also serves participants of the Badan Penyelenggara Jaminan Sosial (BPJS) so that the Jemursari Hospital serves BPJS patients without charging extra fees and there is no differentiation of facilities and services for general patients and BPJS participating patients. Therefore Jemursari Surabaya Islamic Hospital is one of the hospitals that must pay attention to the maximum supply that can be provided in providing health services.

Resources in the economy are better known as the abbreviation 6M2T1I, which includes Man, Money, Method, Machine, Market, Material, Time, Technology, and Information. It is important to be able to identify from 6M2T1I from Jemursari Islamic Hospital because it can affect the activities of meeting the needs of the consumers' requests and the availability of goods or services from the producers.

In health services, the main resources needed to meet the needs of consumers or patients include the availability of health workers (Man) and medical equipment needed (Machine). But in addition to these resources, it is necessary to know other resources needed such as the period in the service (Time). The implementation of health services is expected to maintain a balance between available resources and needs and patients in health services.

But not every health services have the resources that can meet the needs of patients. Departing from this requires an effort to accommodate these resources, it is necessary to measure the ability of services that can be provided by the Islamic Hospital of Jemursari Surabaya so that it can be compared to how much service should be provided with the service provided. This will be useful for the implementation of effective and optimal health care activities without causing harm to any side. Therefore, this journal will analyze the maximum supply at the Medical Rehabilitation Poly, General Surgical Poly, Child Poly Room A, and Child Poly Room B at Jemursari Surabaya Islamic Hospital in a matter of 1 period in 1 day. Maximum supply analysis was obtained through maximum supply calculation at Medical Rehabilitation Poly at Jemursari Surabaya Islamic Hospital, maximum supply calculation at General Surgical Poly at
Jemursari Surabaya Islamic Hospital, maximum supply calculation on Children's Poly Room A at Jemursari Surabaya Islamic Hospital, and supply calculation maximum in Children's Poly Room B at Jemursari Islamic Hospital Surabaya. Maximum supply analysis in these poly due to limitations in the availability of data based on permits granted by the hospital.

\section{METHOD}

This type of research is descriptive observational research. The design of this type of research is cross sectional with data collection at one time.

Subjects in this study were Medical Rehabilitation Poly, General Surgical Poly, Children's Poly Room A and Children's Poly Room B , at Jemursari Islamic Hospital with the object that the maximum capacity for health services can be provided in Medical Rehabilitation Poly, General Surgical Poly, Children's Poly Room A and Children's Poly Room B. The type of data for this study is quantitative and qualitative data. Quantitative data is in the form of length of time available for one-time service, number of tools, length of time available, etc. Qualitative data is in the form of identification of the resources possessed by the Medical Rehabilitation Clinic at Jemursari Islamic Hospital, Medical Rehabilitation Poly, General Surgical Poly, Children's Poly Room A and Room B.

Data collection during the study period uses secondary data and primary data. Secondary data was obtained through data related to service activities in Medical Rehabilitation Poly, General Surgical Poly, Children's Poly Room A and Children's Poly Room B such as the number of available equipment and patient visit data. While primary data is obtained through indepth interviews and observations of related parties such as nurses in each poly. The data analysis technique in this study is a descriptive observational analysis technique to see the maximum service capacity that can be given by Medical Rehabilitation Poly, General Surgery Poly, Children's Poly Room A and Children's Poly Room B at Jemursari Islamic Hospital so as to improve services. 


\section{RESULT}

Maximum Supply Health Services in Medical Rehabilitation Poly at Jemursari Islamic Hospital Surabaya

Based on Supply Maximum data collection that has been carried out in the Medical Rehabilitation Service, primary data and secondary data are obtained which are used to identify elements in the Supply Maximum calculation, namely as follows:

\section{Identification of Resources:}

a) Man: 10 physiotherapy health workers. b) Material: medicine, ointment, cotton, and others. c) Machine: 10 beds. d) Market: All community patients referral to Medical Rehabilitation in Jemursari Hospital and independent patients. e) Technology: Bed therapy. f) Time: Service opening time starts at $07.00-22.00$ WIB for 6 working days a week, 12 hours each day for 25 working days in 1 month. g) Information: Poster contains information about service time, poly opening hours and posters about physiotherapy.

\section{The most dominant resource}

The most dominant resource in providing services to patients in the Medical Rehabilitation Poly of Jemursari Surabaya Islamic Hospital is a therapy bed and a number of physiotherapy health workers. While other resources are assumed to be supporting factors and are assumed to have been fulfilled. In the Medical Rehabilitation Service there are 10 therapy beds and 10 physiotherapy health workers.

\section{Identify Available Times}

The service hours at the Medical Rehabilitation Poly at Jemursari Surabaya Islamic Hospital began at 07.00 - 22.00 WIB. The day break starts at $13.30-15.30$ WIB and the afternoon break starts at $17.30-18.30$ WIB. So it is assumed that in a full day of Medical Rehabilitation Medical services at Jemursari Surabaya Islamic Hospital is 15 hours -3 hours $=12$ hours each day or equal to 720 minutes each day. So the time available in 1 day is 720 minutes for service.

\section{Identify Time in 1 service}

The average patient care at the Jemursari Surabaya Islamic Hospital Medical Rehabilitation Poly is 39 minutes. Calculations are obtained from the average service time for various actions including; baby massage (30 minutes), pregnancy exercise (45 minutes), osteoporosis exercise (60 minutes), speech therapy (30 minutes), bobat exercise (30 minutes).

Maximum Supply Calculation in Supply Maximum in Medical Rehabilitation Poly, Jemursari Surabaya Islamic Hospital. Maximum Supply = (length of time available) / (length of service per patient) $x$ number of equipment and health workers

Maximum Supply $=(720$ minutes $) /(39$ minutes) x 10

Maximum supply $=185$ services in 1 day

So in a day the maximum number of patients who can be given service is 185 patients.

Maximum Supply Health Services in General Surgical Poly at Jemursari Islamic Hospital Surabaya

Based on Maximum Supply data collection that has been carried out in General Surgical Poly Services, primary data and secondary data are obtained which are used to identify elements in Maximum Supply calculations, namely as follows:

\section{Identification of Resources:}

a) Man: 2 surgeons, 2 administrative officers, 1 pharmacist, 3 pharmacist assistants, and 1 janitor. b) Machine: 2 Hecting Set (Stitch Stitch Lift, Anatomical Tweezers, Chirugis Tweezers, Bandage Scissors, Tissue Scissors) and 1 stethoscope. c) Material: 1 meter, 1 weight scale as well as a height gauge, 1 stethoscope, 1 bed, 1 examination room, 1 sink, 1 medical bins, 1 non-medical bins. 1 table, 4 chairs, 1 cupboard. d) Market: the whole community, with an average visit of 50 patients per day. e) Technology: 1 set of computers. f) Time: 30 hours per week for 4 weeks in 1 month. g) Information: Does not use special information media.

\section{The most dominant resource}

The most dominant resource in providing services to patients is the number of surgical specialists, 1 Hecting Set (Seam Lift Scissor, Anatomical Tweezers, Chirugis Tweezers, Bandage Scissors, Tissue Scissors) and 1 stethoscope available at Jemursari Surabaya Hospital Medical Surgery. 1 Hecting Set (Stitch Stitching Scissors, Anatomical 
Tweezers, Chirugis Tweezers, Bandage Scissors, Tissue Scissors) and 1 stethoscope are tools that are always used in every patient. While surgeons have a dominant role to do the examination of patients in the general surgical poly.

\section{Identify Available Times}

The opening hours of the General Surgery Poly of Jemursari Surabaya Hospital are 5 hours a day. So the time available in 1 day is 300 minutes for service.

\section{Identify Time in 1 service}

An average of 1 service takes 15 minutes.

\section{Maximum Supply Calculation in Maximum} Supply in General Surgical Poly Services, Jemursari Surabaya Islamic Hospital

Maximum Supply = (length of time available) / (length of service per patient) $\mathrm{x}$ number of equipment and health workers

Maximum Supply $=(300$ minutes $) / 15$ x 2

Maximum supply $=40$ services in 1 day

So in a day the maximum number of patients who can be given service is 40 patients.

Maximum Supply of Health Services in Children's Poly Room A at Jemursari Islamic Hospital Surabaya

Based on Maximum Supply data collection that has been carried out in the Children's Poly Service Room A, primary data and secondary data are obtained to identify elements in the Maximum Supply calculation, namely as follows:

\section{Identification of Resources:}

a) Man: 3 specialists and 2 nurses. b) Machine: 1 pediatric stethoscope, 1 child thermometer, 1 child weighing scale, 1 sphygmomometer and child cuff, 1 body height meter. c) Material: medicine, cotton, needle. d) Market: Users of this service unit are sick children and come to the hospital. e) Technology: Stethoscope, Spygmomanometer, ECG Otoscope. f) Time: Children's Poly Opening Hours are Monday Friday: 08.00 - 21.00 WIB, Saturday: 08.00 13.00 WIB and Sunday / red date: Close. Rest Hours on Monday - Friday: 13.00-16.00 WIB. Time needed in $1 \mathrm{x}$ service: 15 minutes / patient. g) Information: Notifies the patient's website address, distributes promotional catalogs, requests consumer data, distributes calendars.

\section{The most dominant resource}

The most dominant resource in providing services to patients is the number of pediatric specialists and pediatric stethoscopes available at Children's Poly. Pediatric stethoscope is a tool that is often used to examine patients in pediatric poly. While pediatricians have a dominant role to conduct examinations for patients in the Children's Poly. There are 3 specialists in the Children's Poly Room A in the Islamic Hospital of Surabaya (but in a day there are only 2 doctors in the clinic with alternating time shifts) with 1 pediatric stethoscope.

\section{Identify Available Times}

Children's Poly Room A Opening Hours are Monday - Friday: 08.00 - 21.00 WIB, Saturday: 08.00 - 13.00 WIB and Sunday / red date: Close. Rest Hours on Monday - Friday: 13.00-16.00 WIB. So the amount of time available in one period is 10 hours or 600 minutes of service a day.

\section{Identify Time in 1 service}

In one service, each patient gets 15 minutes of service.

Maximum Supply Calculation in Supply Maximum in Children's Poly Service Room A, Islamic Hospital Jemursari Surabaya Maximum Supply = (length of time available) / (length of service per patient) $\mathrm{x}$ number of equipment and health workers

Maximum Supply $=(600$ minutes $) / 15 \times 1$

Maximum supply $=40$ services in 1 day

So in a day the maximum number of patients who can be given service is 40 patients.

Maximum Supply of Health Services in Children's Poly Room B at Jemursari Islamic Hospital Surabaya

Based on Maximum Supply data collection that has been carried out in the Children's Poly Service Room B, primary data and secondary data are obtained to identify elements in the Maximum Supply calculation, namely as follows:

\section{Identification of Resources:}

a) Man: 3 specialists and 2 nurses. b) Machine: 2 pediatric stethoscope, 2 child thermometer, 1 child weighing scale, 1 sphygmomometer and child cuff, 2 body height meter. c) Material: medicine, cotton, needle. d) Market: Users of 
this service unit are sick children and come to the hospital. e) Technology: Stethoscope, Spygmomanometer, ECG, Otoscope. f) Time: Children's Poly Opening Hours are Monday Friday: 08.00 - 21.00 WIB, Saturday: 08.00 13.00 WIB and Sunday / red date: Close. Rest Hours on Monday - Friday: 13.00-16.00 WIB. Time needed in $1 \mathrm{x}$ service: 15 minutes / patient. g) Information: Notifies the patient's website address, distributes promotional catalogs, requests consumer data, distributes calendars.

\section{The most dominant resource}

The most dominant resource in providing services to patients is the number of pediatric specialists and pediatric stethoscopes available at Children's Poly. There are 3 specialists in the Children's Poly Room B in the Islamic Hospital of Surabaya (but in a day there are only 2 doctors in the clinic with alternating time shifts) with 2 pediatric stethoscope.

\section{Identify Available Times}

Children's Poly Room A Opening Hours are Monday - Friday: 08.00 - 21.00 WIB, Saturday: 08.00 - 13.00 WIB and Sunday / red date: Close. Rest Hours on Monday - Friday: 13.00-16.00 WIB. So the amount of time available in one period is 10 hours or 600 minutes of service a day.

\section{Identify Time in 1 service}

In one service, each patient gets 15 minutes of service.

Maximum Supply Calculation in Supply Maximum in Children's Poly Service Room A, Islamic Hospital Jemursari Surabaya

Maximum Supply = (length of time available) / (length of service per patient) $x$ number of equipment and health workers

Maximum Supply $=(600$ minutes $) / 15$ x 2

Maximum supply $=80$ services in 1 day

So in a day the maximum number of patients who can be given service is 40 patients.

\section{DISCUSSION}

Maximum Supply Health Services in Medical Rehabilitation Poly at Jemursari Islamic Hospital Surabaya

At the Medical Rehabilitation Poly at Jemursari Islamic Hospital Surabaya the most dominant resource is Man, in the form of 10 physiotherapy health workers and 10 therapeutic beds with a total period of 12 hours or 720 minutes, as well as average service time average of 39 minutes was obtained from the calculation of various actions in Medical Rehabilitation Poly. Based on the calculation of the maximum supply in Medical Rehabilitation Poly, the maximum number of patients who can be given as many as 185 patients each day is obtained. However, based on the in depth interview the number of patients served per day was 150 patients each day. So that based on the results of a maximum supply analysis, Medical Rehabilitation Poly at Jemursari Surabaya Islamic Hospital almost fulfills the amount obtained from the supply to a maximum or about $81 \%$ of the maximum supply. This shows that the use of resources in Medical Rehabilitation Poly has not been maximally utilized so that an increase in the number of patient visits is needed.

Maximum Supply Health Services in General Surgical Poly at Jemursari Islamic Hospital Surabaya

The dominant type of resource in Jemursari Surabaya RSI General Surgical Poly was the number of surgical specialists (man) available to check patients every day and (machine) as many as 2 people along with 2 Hecting Sets (Seam Lift Scissors, Anatomical Tweezers, Chirugis Tweezers, bandage scissors, network scissors) and 1 stethoscope. Based on the maximum supply calculation in General Surgical Poly, the maximum number of patients can be given as many as 40 patients each day. However, based on the in depth interview the number of patients served each day was 45 patients each day. So that based on the results of a maximum supply analysis, the Jemursari Surabaya Islamic Hospital General Surgery Polyexceeds the amount obtained by the maximum supply or about $112 \%$ of the maximum supply. This shows that the use of resources in General Surgical Poli has been maximally utilized so that it needs additional poly opening hours General Surgery.

\section{Maximum Supply of Health Services in Children's Poly Room A at Jemursari Islamic Hospital Surabaya}

The dominant type of resource available in the Children's Poly Services Room A of Jemursari Surabaya Islamic Hospital is the number of doctors (man) available to examine patients every day are 3 pediatrics and 2 
nurses. Based on the maximum supply calculation in the Children's Poly Room A is the maximum number of patients who can be given service as many as 40 patients per day. However, based on an in-depth interview the number of patients served per day was 50 patients per day. So that based on the results of the maximum supply analysis, Children's Poly Room A in Jemursari Surabaya Islamic Hospital exceeds the amount obtained from the supply maximum or about $125 \%$ of the maximum supply. This shows that the use of resources in Children's Room A has been maximally utilized so that it needs an additional check room and additional service hours and the addition of a number of medical devices so that patients can be served more.

\section{Maximum Supply Health Services in Children's Poly Room B at Jemursari Islamic Hospital Surabaya}

The dominant type of resource available in the Children's Poly Room B Services of Jemursari Surabaya Islamic Hospital is the number of doctors (man) available to check patients every day is 6 people. Based on the maximum supply calculation in the Children's Poly Room B, the maximum number of patients who can be given 80 services is obtained. patients per day. However, based on an in-depth interview the number of patients served per day was 50 patients per day. So that based on the results of a maximum supply analysis, the Jemursari Surabaya Islamic Hospital Children's Poly Room B exceeds the amount obtained by the maximum supply or about $62.5 \%$ of the maximum supply. This shows that the use of resources in Children's Poly Room B is underutilized so that more labor and tools are needed so that patients can be served more.

The discussion above has shown that there are polys that almost reach the maximum supply figure and there are polys that exceed the maximum supply. This can be influenced by several factors from 6M2T1I. Therefore some of the dominant resource that can be attempted to improve the maximum supply as follows:

\section{Man}

Improvement efforts that can be done on Man or health workers in health services are through increasing discipline (adhering to practice schedules so that they are not late), improving relationships with patients in performing services (explaining the patient's condition in understandable language, caring for patients, etc.) as well as improving the ability of health workers (training, seminars, workshops, etc.). Because based on research by (Suaedi, 2017), the factors that support the development of Human Resources competencies are more due to the type of training itself. In this case, the type of training that is proven to be able to improve employee competencies is training related to technical abilities, because this type of training is held to develop skills (skills), not knowledge or attitude.

\section{Machine}

Machine is one of the dominant resources in health services. So that the availability of the machine must always be maintained and balanced with the capacity of Man (health personnel). The dominant machine in the Jemursari Islamic Hospital to complete a health service such as a pediactric stethoscope, nebulizer, hecting set, therapeutic bed, etc.

\section{Time}

Poly in Jemursari Surabaya Islamic Hospital have set a practice schedule and rest hours. However, after the maximum supply calculation, there is a poly that exceeds the maximum supply limit so that there is a policy regarding time management.

Hermanti (2017) states that creating an Operational Standard Procedure for the timeliness of doctors, nurses, and administrative officers in serving, the standard time of each type of service and the standard waiting time for services can be carried out to improve the discipline of nurses and doctors in charge of each poly.

\section{CONCLUSION}

The number of Medical Rehabilitation Poly visits at Jemursari Surabaya Islamic Hospital in October 2017 was 150 patients. The number of the General Surgery Poly visits at Hospital of Jemursari Surabaya Islamic Hospital in October 2017 was 45 patients. The number of visits by Child Poly Room A of Jemursari Surabaya Islamic Hospital in October 2017 was 50 patients. The number of visits by Child Poly in Room B of Jemursari Surabaya Islamic Hospital in October 2017 
was 50 patients. The results of the maximum supply calculation in Medical Rehabilitation Poly amounted to 185 patients each day, when compared to the history of the numbers of Medical Rehabilitation Poly visits at the Jemursari Surabaya Islamic Hospital at 150 patients each day. Maximum supply calculation in General Surgical Poly is 40 patients each day, when compared to the history of the number of Medical Rehabilitation visits of Jemursari Surabaya Islamic Hospital at 45 patients each day. The results of the maximum supply calculation in Children's Poly Room A is 40 patients each day, when compared to the history of the number of visits by the Poli of Jemursari Surabaya Islamic Hospital at 50 patients each day. The maximum supply calculation results in Children's Poly Room B is 80 patients each day, when compared to the history of the number of visits of Children's Poly Jemursari Surabaya Islamic Hospital at 50 patients each day. From the result above is known that Medical Rehabilitation Poly and Children's Poly can be said to be over supply, because those two poly have a greater supply capacity compared to the history of poly visit data. While General Surgery Poly is in the opposite condition because the maximum supply calculation results are smaller than the historical data of the visit.

Based on the results above, there are several related scope in Jemursari Islamic Hospital Surabaya that are able to deal with the appropriate conditions. One of them is to advocate for the development needs of the interior and exterior of the Children's Poly Room so that services can run well, and advocacy related to the regulation, planning, drafting and stipulation of policies and procedures for Medical and Nursing services in regulating service hours which can be delivered through the Bidang Umum in Jemursari Islamic Hospital Surabaya.

\section{SUGGESTIONS}

Jemursari Islamic Hospital Surabaya is one hospital that has experienced with very significant growth. However, from the maximum capacity that can be provided in services known through the calculation of maximum supply there are several things that can be used as inputs. Hospitals can develop market strategies to increase the number of visits so as to maximize the maximum supply capacity that has not been met, such as those in the Medical Rehabilitation Poly and Children's Poly. Whereas for poly which exceeds the maximum supply, namely General Surgery Poly, there must be a policy of adding poly opening hours because based on the results obtained when going down the field, General Surgery Poly opening hours are only 5 hours each day.

Suggestions that can be given based on the results of in-depth interviews for the Medical Rehabilitation Poly are setting service hours because services reach 12 hours a day. While maximum supply results indicate oversupply. It is hoped that changes in service hours will also consider health personnel and the machines used. General Surgery Poly is to increase service hours because service hours are only 5 hours a day while patient visit data is greater than maximum supply. For Children's Poly there must be additional space because it is not comparable with the number of specialist doctors totaling 6. Human and machine resources are supported but lacking in providing room to hold the health service.

\section{REFERENCE}

Alexander Hamilton Institute (U.S.). 1994. Management audit: maximizing your company's efficiency and effectiveness. Maywood, NJ : Alexander Hamilton Institute.

Ardiyati, A. 2011. Penawaran Daging Sapi di Indonesia (Analisis Proyeksi Swasembada Daging Sapi 2014). Universitas Indonesia. Diakses dari: http://lib.ui.ac.id/file?file=digital/2029 0082-T 29569-Penawaran daging-full text.pdf.

Daniel, M. 2004. Pengantar Ekonomi Pertanian. Jakarta: Bumi Aksara.

Haryanto, J. O. and Ollivia. 2009. Pengaruh Faktor Pelayanan Rumah Sakit, Tenaga Medis, dan Kualitas Pelayanan Rumah Sakit Terhadap Intensi Pasien Indonesia Untuk Berobat di Singapura. Jurnal Ekonomi Bisnis, 14(2), pp. 144-151. Diakses dari https://ejournal.gunadarma.ac.id/index. php/ekbis/article/view/315.

Hermanti, P. 2017. Kepuasan Pelanggan Berdasarkan Dimensi Timeliness Kualitas Jasa Evans dan Lindsay Dengan Metode Importance Performance Analysis. Jurnal 
Administrasi Kesehatan Indonesia, 5(1), pp. 82-90. Diakses dari: https://ejournal.unair.ac.id/JAKI/article/view/7 $053 / 0$

Kahar, K. 2016. Analisis Rasio Kinerja Keuangan Rumah Sakit Umum Bahteramas Sulawesi Tenggara. Jurnal Akuntansi, pp. 1-14.

Lestari, S. .2015. Hubungan Komunikasi Pemasaran Dan Promosi Dengan Keputusan Memilih Jasa Layanan Kesehatan (Studi Pada Rumah Sakit Islam Lumajang). Interaksi: Jurnal Ilmu Komunikasi, 4(2), pp. 139-147. Diakses dari: https://ejournal.undip.ac.id/index.php/i nteraksi/article/view/9757.

Nurjayanti, E. 2011. Peramalan Penawaran dan Permintaan Beras Pada Era Otonomi Daerah di Kabupaten Sukoharjo. Universitas Negeri Surakarta.

Pebrianti. 2015. Manajemen Logistik pada Gudang Farmasi Rumah Sakit Umum
JPH RECODE Oktober 2019; 3 (1) : 28-36

Daerah Kabelota Kabupaten Donggala, e-Jurnal Katalogis, 3(7), pp. 127-136. Diakses dari: http://jurnal.untad.ac.id/jurnal/index.ph $\mathrm{p} /$ Katalogis/article/view/6383.

Suaedi, F. 2017.Pengembangan Kompetensi Sumber Daya Manusia dalam Rangka Meningkatkan Pelayanan di Rumah Sakit Haji Surabaya, Al-Tijarah, 3(1), pp. 79-102. Diakses dari: https://ejournal.unida.gontor.ac.id/inde x.php/altijarah/article/view/939.

Susilo, A. 2017. Analisis Supply Maksimum Pelayanan Kesehatan di UPTD Puskesmas Ngadiluwih. Jurnal Penelitian Kesehatan Suara Forikes, 8(1), pp. 6-10.

Yoeti, O. 2008. Ekonomi Pariwisata: Introduksi, Informasi, dan Implementasi. Jakarta: Penerbit Buku Kompas. 